\title{
PKM KELOMPOK PKK DAN KELOMPOK TANI DUSUN SIDOMULYO DESA LIMBUNG KECAMATAN SUNGAI RAYA KABUPATEN KUBURAYA KALIMANTAN BARAT
}

\author{
PKM PKK Group and Farmer Groups Usaha in Limbung Village \\ Sungai Raya sub-district Kuburaya Regency West Kalimantan \\ Muflihah Ramadhia ${ }^{1)}$, Abdullah ${ }^{2)}$ \\ ${ }^{1}$ Jurusan Teknologi Hasil Perkebunan Politeknik Negeri Pontianak \\ ${ }^{2)}$ Jurusan Administrasi Bisnis, Politeknik Negeri Pontianak \\ Korespondensi penulis, Email: ramadhia 99@yahoo.com
}

\begin{abstract}
PKK groups and farmer group usaha in Sidomulyo are active partners of the community service activities provided. This activity aims to provide skills and expertise to partners to have the ability to process aloe vera into processed food products that can be sold in the market. The method that was carried out was by demonstrating processing aloe vera into processed food in the form of: syrup, jam, jelly candy, biscuits, pudding and aloe vera tea. The results obtained conclude that syrup can be accepted by 16 and cannot receive 4 people. The bride can be accepted by 18 and cannot receive 2 people. Jelly candy can be accepted by all respondents $(20$ people), biscuits can be accepted by 18 and cannot accept 2 people, the pudding can be accepted by all respondents (20 people) and aloe vera tea is received by 18 and cannot receive 2 people. The conclusion of this activity is that partners are able to process Aloe Vera products into products that are generally acceptable to consumers.
\end{abstract}

Keywords: PKK, farmer groups, skills, aloe vera, processed products

\begin{abstract}
ABSTRAK
Kelompok PKK dan Kelompok Tani Usaha dusun Sidomulyo merupakan mitra aktif dari kegiatan pengabdian masyarakat yang diberikan. Kegiatan ini bertujuan memberikan keterampilan dan keahlian kepada mitra untuk memiliki kemampuan dalam mengolah lidah buaya menjadi olahan produk pangan yang dapat dijual dipasaran. Metoda yang dilakukan adalah dengan melakukan demonstrasi mengolah lidah buaya menjadi olahan pangan berupa: sirup, selai, permen jelly, biskuit, pudding dan teh kulit lidah buaya. Hasil yang diperoleh menyimpulkan bahwa sirup dapat diterima oleh 16 dan tidak dapat menerima 4 orang.Selai dapat diterima oleh 18 dan tidak dapat menerima 2 orang. Permen jelly dapat diterima seluruh responden (20 orang), biskuit dapat diterima oleh 18 dan tidak dapat menerima 2 orang, pudding dapat diterima seluruh responden (20 orang) dan teh kulit lidah buaya diterima oleh 18 dan tidak dapat menerima 2 orang. Simpulan dari kegiatan ini adalah mitra mampu mengolah produk olahan lidah buaya menjadi produk yang umumnya dapat diterima
\end{abstract} konsumen.

Kata Kunci: PKK, kelompok tani, keterampilan, lidah buaya, produk olahan

\section{PENDAHULUAN}

Dusun Sidomulyo merupakan bagian desa Limbung yang terletak di kecamatan Sungai Raya, Kabupaten Kubu Raya Kalimantan Barat. Jarak dusun ini dengan desa Limbung $\pm 25 \mathrm{~km}$ dan jarak menuju
Politeknik Negeri Pontianak $\pm 43 \mathrm{~km}$. Desa Limbung secara keseluruhan memiliki luasan wilayah $50.000 \mathrm{Ha}$, dengan luasan ini beberapa bagiannya diusahakan dalam sektor pertanian beragam seperti tomat, jagung dan tanaman lidah buaya.Namun kesemua hasil pertanian yang dimiliki 
belum tersentuh teknologi olah menjadi ragam produk, sehingga pendapatan sangatlah tergantung pada pasar lokal.

Dusun Sidomulyo saat ini tercatat memiliki kelompok aktif yang tergabung dalam wadah yang diberi nama kelompok PKK Dusun Sidomulyo dan Kelompok Tani Sukamaju. Hasil survei dilapangan ditemukan bahwa pertemuan yang dilakukan belum pernah mengarah padawirausaha apapun karena minimnya informasi mengenai hal positif yang dapat diterima terhadap wirausaha,utamnyadengan melirik sumberdaya lokal yang dimiliki, sehingga ini menjadikan peluang yang sangat berarti untuk dimunculkan sebagai upaya meningkatkan ekonomi keluarga. Hasil survei lanjutan yang dilakukan menyimpulkan bahwa warga Dusun Sidomulyo mengharapkan pembimbingan dan pengarahan untuk hidup lebih maju dengan melakukan kegiatan baru dengan wirausaha. (Wawancara tim pengusul dengan warga). Simpulan yang dapat diambil dari propil mitra adalah pada hakikatnya kedua mitra memiliki semangat, waktu, tempat dan kesempatan untuk bersatu, berkarya, berinovasi dan berkreasi menjadi masyarakat maju dan sejahtera namun butuh arahan dan bimbingan.

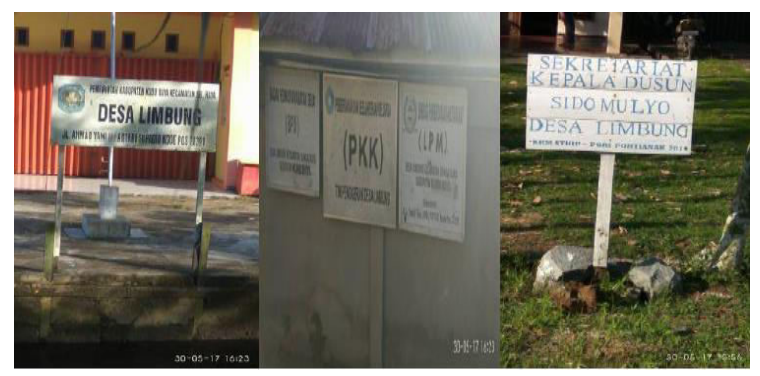

Gambar 1. Foto lokasi mitra

Dusun Sidomulyo memiliki potensi terkait sumber daya alam dan sumber daya manusia.Sisi peninjauan sumber daya alam dalam bidang tanaman pertanian khususnya lidah buaya sangat menjanjikan. Menurut Narsih et al.(2012) lidah buaya memiliki senyawa bioaktif seperti aktivitas antioksidan sebesar $86,16 \%$ dan 11 senyawa volatile yang berperan sebagai antioksidan. Narsih et al.(2013) juga menyebutkan bahwa sifat bioaktif dari phytokomponennya dapat berfungsi sebagai agen antioksidan dan Narsih dan Agato (2016)menyebutkan kulit lidah buaya juga memiliki komponen bioaktif yang sangat bermanfaat. Penelitian lain di publikasikan oleh Eshun dan $\mathrm{He}$ (2004), bahwa tanaman tropis atau subtropiks seperti lidah buaya digunakan dalam obat rakyat, kosmetik, suplemen dan bahan makanan dan penelitian Miladi dan Damak (2008) mencatat bahwa aloe vera mengandung senyawa farmasi, sehingga dapat diaplikasikan menjadi produk farmasi dan pangan, sehingga sangat memungkinkan untuk membuat berbagai olahan berbasis lidah buaya dengan harapan terciptanya produk sehat yang dinantikan dari sisi ekonomis dan kesehatan.

Adanya keterkaitan antara analisis situasi yang menguraikan pontensi daerah, peluang usaha, sumber daya mitra yang dimiliki untuk mengembangkan peluang usaha baru, tetapi kurangnya informasi teknologi tepat guna, namun motivasi dan semangat tinggi untuk terus berkreativitas menjadi masyarakat ekonomi produktif, maju, mandiri dan sejahtera merupakan permasalahan yang disepakati antara pengusul dan mitra untuk diberikan solusi real dalam penyelesaiannya yaitu pelatihan pengolahan aneka produk olahan lidah buaya.

\section{BAHAN DAN METODE}

\section{Bahan}

Bahan yang digunakan dalam pengolahan aneka makananterdiri dari lidah buaya yang dibeli diwilayah Pasar Rasau Jaya dengan spesifikasi umur 8 bulan, sedangkan bahan-bahan untuk pembuatan produk yaitu: 1) sirup : gula pasir, garam, daun pandan, pewarna makanan, cengkeh, kayu manis, Natrium benzoat, asam sitrat, 2)selai:gula garam, natrium benzoate, pewarna makanan dan telur 3) permen jelly kering: garam, gula, agar-agar, tepung maezena, pewarna makanan 4) cookies: gula, garam, terigu, maezena, tepung sagu, 
telur, margarine, baking powder, soda kue, manik asesorie makanan dan susu bubuk. 5) Teh kulit lidah buaya: kulit lidah buaya kering dan garam

\section{Alat}

Kompor gas, panci (besar, sedang, kecil), baskom (besar, sedang, kecil), pisau, talenan, nyiruk, talenan, pengupas, cup kemasan, cup selai, kertas bungkus kue, palsti pp,pe, serbet, tisu, gelas literan, timbangan, blender, mixer, kuali, pengaduk, kayu dan plastik, oven, tirisan, pencetak, sendok, toples kaca, toples platik, Loyang, celemek, ayakan, pencetak pudding, sealer, cetakan biskuit, celemek, sarung tangan plastic, sutil.

\section{Aspek Proses Produksi Olahan}

\section{Pengolahan Sirup}

Lidah buaya dibersihkan dan diambil bagian gelnya dipotong dadu dan direndam dengan garam $15 \%$ selama 1,5 jam. Selanjutnya dicuci dengan air bersih mengalir sampai lendir terasa berkurang, dilanjutkan dengan pemblancingan selama 5 menit, setelah gel dingin, dilanjutkan dengan penghancuran menggunakan blender dan penyaringan untuk memperoleh sarinya, dilain sisi disiapkan gula pasir dan sari lidah buaya masak hingga mendidih dan dimatikan sumber panasnya.Setelah campuran keduanya menjadi hangat ditambahkan natrium benzoate dan pewarna makanan dan kemas dalam botol yang telah disterilisasi.

\section{Pengolahan Selai}

Gel lidah buaya dipotong dadu dan direndam dengan garam selama 1 jam selanjutnya potongan lidah buaya direbus untuk memastikan hilangnya lendir. Gel kemudian ditiriskan dan ditambahkan kembali air bersih yang ditambah gula pasir dan garam secukupnya, diaduk hingga merata serta ditambahkan tepung maezena secukupnya untuk membentuk konsistensi selai, terakhir ditambahkan daun pandan sebagai aroma dan dikemas dalam cup dan lemari pendingin.

\section{Pengolahan Permen jelly}

Gel lidah buaya dihaluskan dengan blender dan dituangkan kedalam panci, kemudian ditambahkan gula pasir sambil diaduk, lakukan pemasakan pada api sedang dan setelah matang, adonan diangkat dan dibagi menjadi beberapa bagian dengan penambahan warna yang berbeda. Selanjutnya adonan dituang dalam loyang pencetak, jika sudah beku lakukan pemotongan sesuai selera dan dijemur selama 5 hari jika cuaca panas dan setelah kering dikemas dengan plastik.

\section{Pengolahan cookies}

Gel lidah buaya disiapkan kemudian dihaluskan. Sisi lain mengocok telur kuning 3 buah, gula pasir 100g,margarine $100 \mathrm{~g}$, baking powder dan uleni dengan terigu hingga kalis yang dilanjutkan dengan pencetakan, pemberian topping dan pemangangan selama 45 menit dan pengemasan dengan wadah tersedia.

\section{Pengolahan teh kulit lidah buaya}

Kulit lidah buaya dicuci dengan air bersih dan dipotong tipis memanjang yang dilanjutkan dengan penjemuran selama 4 hari jika menggunakan sinar matahari atau pengovenan selama 3 jam.Selanjutnya dilakukan penghancuran dan bungkus menyerupai teh celup komersial.

\section{Pengolahan puding lidah buaya}

Gel lidah buaya sebanyak $500 \mathrm{~g}$ direbus dalam air mendidih selama 10 menit, ditiriskan dan kemudian dihancurkan dengan blender. Kocok lepas gula pasir $100 \mathrm{~g}$, telur kuning 5 buah, margarine 50gdan vanila secukupnya. Lakukan pemasakan selama 15 menit kemudian di tuang kedalam cetakan.

\section{Metoda Pelaksanaan}

Kegiatan Pengabdian masyarakat ini dilakukan dirumah kediaman Ketua PKK dusun Sidomolya, hal ini dimaksudkan agar semua peserta dapat dengan mudah berkumpul untuk kegiatan yang dimaksud. Kegiatan ini dihadiri 2 mitra yang ditunjuk dengan jumlah personel 20 orang. 


\section{HASIL DAN PEMBAHASAN}

Olahan produk yang dihasilkan kemudian dilakukan uji penerimaan konsumen dilapangan. Konsumen yang dimaksud adalah seluruh peserta pelatihan yang terlibat dalam pengolahan dengan jumlah 20 orang. Hasil yang diperoleh terhadap olahan produk disajikan pada Tabel 1.

Tabel 1. Olahan produk lidah buaya

\begin{tabular}{lcc}
\hline \multirow{2}{*}{ Nama Produk } & \multicolumn{2}{c}{ Penilaian Konsumen } \\
\cline { 2 - 3 } & Menerima & $\begin{array}{c}\text { Tidak } \\
\text { Menerima }\end{array}$ \\
\hline Sirup & 16 & 4 \\
Selai & 18 & 2 \\
Permen Jelly & 20 & 0 \\
Cookies & 18 & 2 \\
Puding & 20 & 0 \\
Teh & 8 & 12 \\
\hline
\end{tabular}

Sumber data: Kuisioner Kegiatan PKM 2018

\section{Produk Sirup}

Produk olahansirup berbahan baku lidah buaya, menyimpulkan bahwa sebanyak 16 orang menerima dalam arti konsumen menyukai dalam hal rasa, konsistensi dan warna yang disajikan.Sirup yang dihasilkan memiliki rasa manis dan khas lidah buaya, konsistensi kental dan warna hijau bening, sehingga membuat konsumen dapat merasakan sensasi lidah buaya aslinya, namun dari sisi warna ditambahkan pewarna tambahan untuk mempertajam warna asli lidah buaya yaitu hijau. Jumlah konsumen yang tidak menyukai sirup berjumlah 4 orang, tidak disukainya produk ini dinilai dari rasa yang terlalu manis dan aroma lidah buaya yang masih tercium.

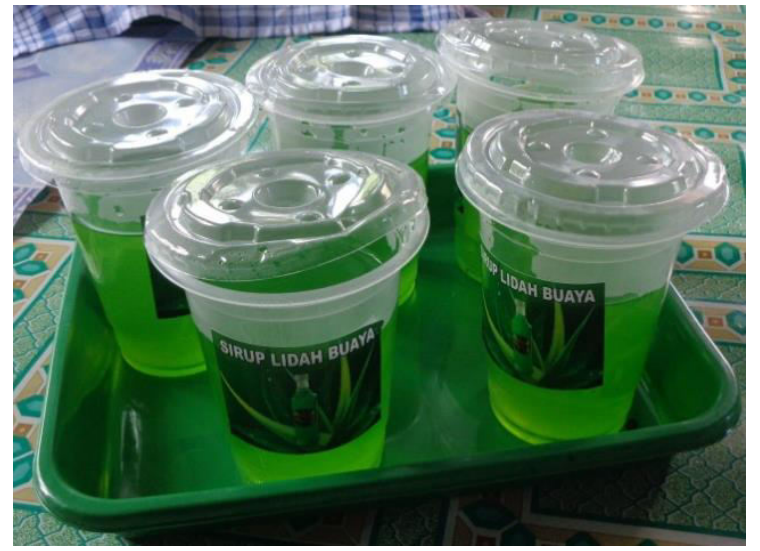

Gambar 2. Sirup lidah buaya

\section{Produk Selai}

Produk selai berbahan baku lidah buaya, menyimpulkan bahwa sebanyak 18 orang menerima dalam arti konsumen menyukai dalam hal rasa yang manis, konsistensi pasta dan warna hijau muda dan daya oles yang baik (pengolesan dilakukan pada roti tawar bentuk lembaran), sedangkan konsumen yang tidak menyukai sebanyak 2 orang. Selai yang dihasilkan memenuhi standar kriteria selai yaitu daya oles yang baik, tidak sineresis, $\mathrm{pH} 4$. Umumnya selai yang baik adalah selai yang memiliki ciri warna yang cemerlang dan transparan, teksturnya lembut dan memiliki cita rasa almi dari bahan baku yang digunakan. Menurut Fachruddin (1997), apabilaselai terlalu asam akan terjadi sineresisyakni keluarnya air dari gel sehingga kekentalan selaiakan berkurang bahkan sama sekali tidak terbentuk gel.

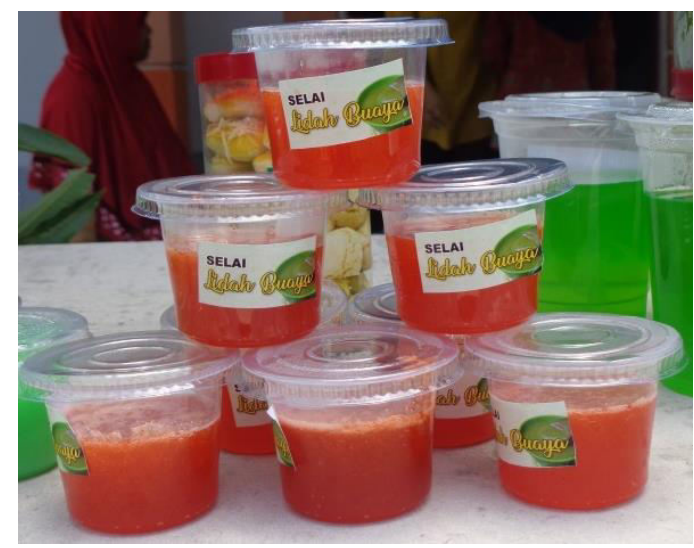

Gambar 3. Selai lidah buaya 


\section{Pengolahan permen jelly}

Permen jelly yang dihasilkan memberikan respon posistif total dari konsumen, yaitu 20 peserta menyatakan suka dari sisi warna, rasa, tekstur dan tampilan. Warna yang digunakan memang bukan warna asli dari bahan melainkan dengan memvariasikan warna lain seperti ungu dan hijau, sehingga diperoleh tiga kombinasi warna. Pemvariasian warna ini didasarkan atas permintaan konsumen, namun tetap menggunakan pewarna makanan, sedangkan rasa yang dihasilkan manis, tekstur kenyal dan tampilan menarik.

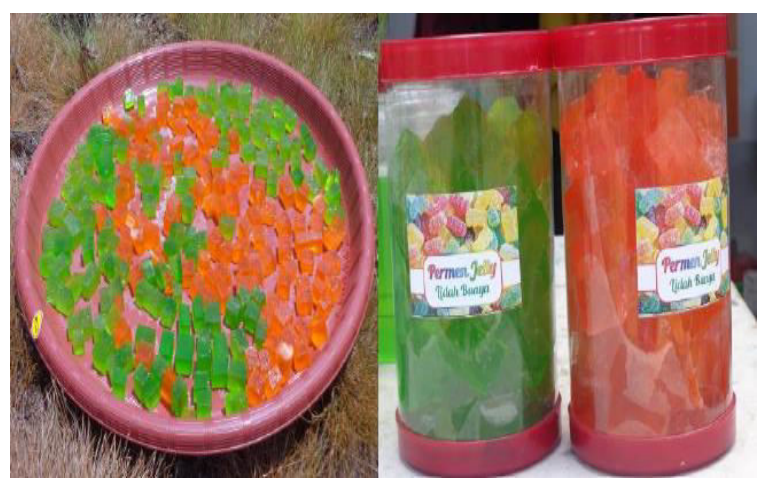

Gambar 4. Permen jelly

\section{Pengolahan cookies}

Biskuit yang dimaksud adalah biskuit kering atau yang lebih dikenal dengan kue kering. Produk ini memperoleh penilaian 18 orang menyukai dan 2 orang yang tidak menyukai. Penilaian biskuit dari sisi organoleptik dari sisi warna adalah kuning kecoklatan.Warna ini disukai oleh konsumen karena kealamian yang diberikan. Warna merupakan sensoris penting dalam menilai kualitas produk, sedangkan dari rasa menghasilkan rasa manis dan sedikit pahit. Rasa manis tentunya diperoleh dari gula yang ditambahkan, sedangkan rasa pahit dimungkinkan karena terikutnya aloin dan saponin dalam lidah buaya yang digunakan. Aloin termasuk kedalam senyawa anthraquinon yang merupakan senyawa kuat pada lidah buaya (Lullmann et al., 2005). Sisi positif aloin menurut Singh et al. (2010) merupakan senyawa pahit yang merupakan obat kulit untuk luka bakar, bahan aktif pencahar, anti obesitas dan penyembuh luka.

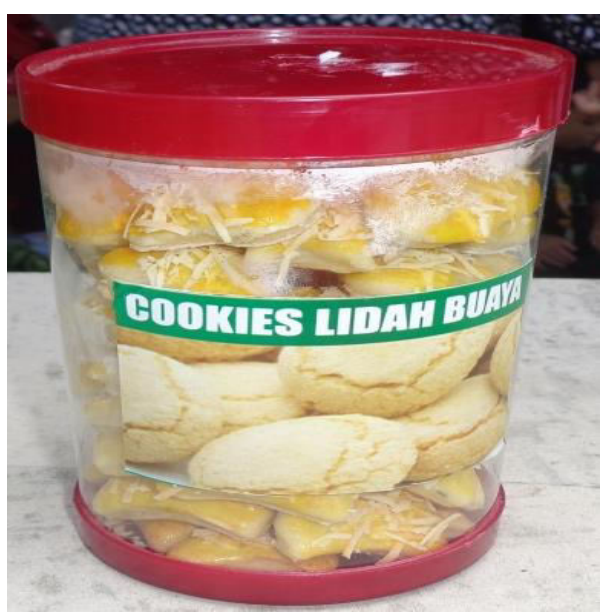

Gambar 5.Cookies lidah buaya

\section{Pengolahan teh kulit lidah buaya}

Teh kulit lidah buaya yang dihasilkan berwarna hijau tua. Produk ini tidak disukai oleh konsumen, hal ini dibuktikan dengan 12 orang dan 8 orang menyukai. Ketidaksukaan konsumen umumnya dikarenakan rasa pahit yang ditimbulkan.Pahitnya teh kulit lidah buaya disebabkan karena senyawa aloin dan saponin yang dimilikinya.Aloin atau yang lebih dikenal sebagai barbaloin merupakan senyawa pahit berwarna kuning kecoklatan yang terdapat pada hampir 68spesies lidah buaya dengan kisaran antara 0,1-6,6\% dari daun lidah buaya (Pillay, 2008). Bozzi et al. (2007) mengemukakan bahwa komponen aloin paling banyak terdapat pada bagian kulit dari pada bagian gel lidah buaya.Sifat saponin juga dikemukakan oleh Supardjo (2010) yaitu: saponin mempunyai rasa pahit, dalam larutan air membentuk busa yang stabil, menghemolisa eritrosit, merupakan racun kuat untuk ikan dan amfibi, membentuk persenyawaan dengan kolesterol dan hidroksisteroid lainnya. 


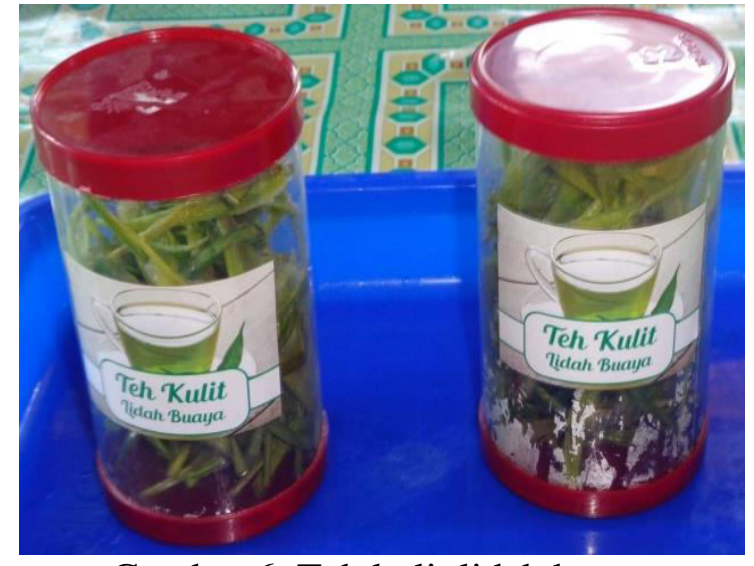

Gambar 6. Teh kulit lidah buaya

\section{Pengolahan puding lidah buaya}

Puding lidah buaya memiliki skor tertinggi berdasarkan penilaian konsumen yaitu seluruh peserta menyukai terhadap produk yang dihasilkan.Seluruh penilaian puding terhadap rasa, warna, tekstur dan tampilan memberikan hal positif pada konsumen terhadap daya terima.

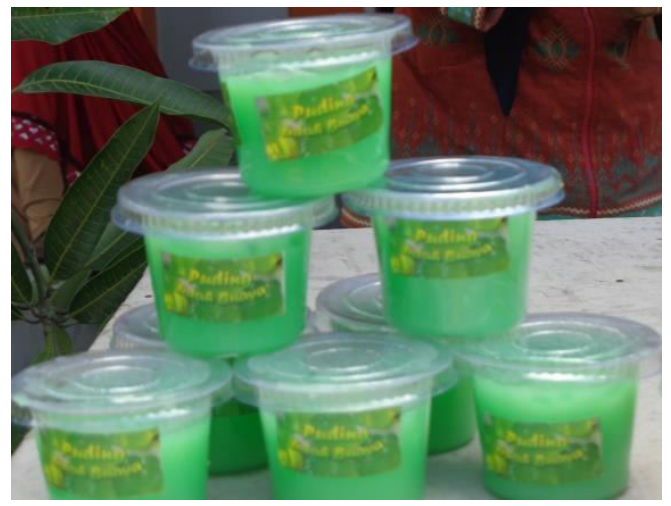

Gambar 7. Puding lidah buaya

\section{KESIMPULAN}

1. Mitra binaan telah memperoleh informasi dan keterampilan, keahlian serta kemampuan dalam mengolah lidah buaya menjadi berbagai produk olahan yang ditargetkan berupa sirup, selai, permen jelly, biskuit, pudding dan teh kulit lidah buaya.

2. Produk yang disukai konsumen berupa sirup, selai, permen jelly, biskuit, pudding, sedangkan teh kulit lidah buaya kurang disukai.

\section{UCAPAN TERIMA KASIH}

Ucapan terimakasih tak terhingga kami sampaikan kepada KEMENRISTEKDIKTI yang telah membiayai seluruh kegiatan pengabdian masyarakat tahun anggaran 2018 dan kepada warga Dusun Sidomulyo atas waktu, kemauan dan semangatnya untuk kesukseksan pelaksanaan kegiatan ini.

\section{DAFTAR PUSTAKA}

Bozzi, A., Perrin, C., Austin, S., \& Vera, F. A. (2007). Quality and authenticity of commercial aloe vera gel powders. Food chemistry, 103(1): 22-30.

Eshun, K., \& He, Q. (2004). Aloe vera: a valuable ingredient for the food, pharmaceutical and cosmetic industries - a review. Critical reviews in food science and nutrition, 44(2): 91-96.

Fachruddin, (1997). Membuat aneka selai. Kanisius.Yogyakarta.

Lullmann, Heinz., Klaus, M., Lutz, H. \& Detlef, B. (2005). Colour atlas of pharmacology 3rd edition. Theime Stuttgart. New York.

Miladi \& Mohammed, D. (2008). In vitro antioxidant activities of aloe vera leaf skin extracts. Journal de la Societe Chimique de Tunisie. 10 : 101-109.

Narsih \& Agato. (2016). Evaluation of bioactive compounds of aloe vera extract using subcritical water method. Biotecnology an Indian Journal, 12 (3): 113120.

Narsih, Kumalaningsih, S., Wijana. S., \& Wignyanto. (2013). Microencapsulation of natural antioxidant powder from Aloe vera (L.) skin using foam mat drying method. International Food research Journal, 20 (1): 285-289.

Narsih, Kumalaningsih, S., Wignyanto, \& Wijana, S. (2012). Identification of aloin and saponin and chemical composition of volatile constituents 
from Aloe vera (L.) Peel J. Agric. Food. Tech., 2(5):79-84.

Pillay, A. (2008). Synthesis and biological activity of aloin derivatives (Doctoral dissertation, University of KwaZuluNatal, Pietermaritzburg).

Singh, B., Yadav, R., Singh, H., Singh, G., \& Punia, A. (2010). Studies on effect of PCR-RAPD conditions for molecular analysis in asparagus (Satawari) and aloe vera medicinal plants. Australian Journal of Basic and Applied Sciences, 4(12): 65706574.

Supardjo. (2010). Saponin peran dan pengaruhnya terhadap ternak dan manusia. Laboratorium Fakultas Peternakan Jambi 